\title{
4-11C-Methoxy $N$-(2-Diethylaminoethyl) Benzamide: A Novel Probe to Selectively Target Melanoma
}

\author{
Pradeep K. Garg ${ }^{1,2}$, Rachid Nazih ${ }^{1,2}$, Yanjun $\mathrm{Wu}^{2}$, Ravi Singh ${ }^{1,3}$, and Sudha Garg ${ }^{1,2}$ \\ ${ }^{I}$ Department of Radiology, Wake Forest University Medical Center, Winston Salem, North Carolina; ${ }^{2}$ Biomedical Research \\ Foundation, Shreveport, Louisiana; and ${ }^{3}$ Department of Cancer Biology, Wake Forest University Medical Center, Winston Salem, \\ North Carolina
}

\begin{abstract}
We report the synthesis and preclinical evaluation of a ${ }^{11} \mathrm{C}$-labeled probe to target melanoma using PET. Methods: The target compound $4-{ }^{11} \mathrm{C}$-methoxy $\mathrm{N}$-(2-diethylaminoethyl) benzamide $\left(4-{ }^{11} \mathrm{C}\right.$ MBZA) was prepared via the ${ }^{11} \mathrm{C}$-methylation of 4 -hydroxy $\mathrm{N}$-(2-diethylaminoethyl) benzamide (4-HBZA). The in vitro binding was performed using B16F1 (melanoma cells), MCF-10A (breast epithelial cells), and MDA-MB 231 (breast cancer cells). The internalization studies were conducted using B16F1 cells. In vivo biodistribution and small-animal PET imaging were performed in mice bearing B16F1 melanoma tumor xenografts. Results: The target compound $4-{ }^{11} \mathrm{C}-\mathrm{MBZA}$ was prepared in $46 \% \pm 7 \%$ radiochemical yields by reacting ${ }^{11} \mathrm{C}$-methyltriflate with 4 -HBZA followed by highperformance liquid chromatography purification. The specific activity of this compound was $853 \pm 29.6 \mathrm{GBq} / \mu \mathrm{mol}(23 \pm 0.8 \mathrm{Ci} / \mu \mathrm{mol})$. The binding of $4-{ }^{11} \mathrm{C}-\mathrm{MBZA}$ to B16F1, MCF-10A, and MDA-MB-231 cells was $6.41 \% \pm 1.28 \%, 1.51 \% \pm 0.17 \%$, and $0.30 \% \pm 0.17 \%$, respectively. Internalization studies using B16F1 melanoma cells show $60.7 \%$ of the cell-bound activity was internalized. Results from biodistribution studies show a rapid and high uptake of radioactivity in the tumor, with uptake levels reaching $5.85 \pm 0.79$ and $8.13 \pm$ 1.46 percentage injected dose per gram at 10 and $60 \mathrm{~min}$, respectively. Low uptake in normal tissues in conjunction with high tumor uptake resulted in high tumor-to-tissue ratios. On small-animal PET images, the tumor was clearly delineated soon after $4-{ }^{11} \mathrm{C}-\mathrm{MBZA}$ injection and tumor uptake reached 4.2 percentage injected dose per gram by $20 \mathrm{~min}$. These preclinical evaluations show a high propensity of $4-{ }^{11} \mathrm{C}-\mathrm{MBZA}$ toward melanoma tumor. Conclusion: We successfully developed $4-{ }^{11} \mathrm{C}-\mathrm{MBZA}$ as a PET imaging probe, displaying properties advantageous over those for its ${ }^{18} \mathrm{~F}$ analogs. These preclinical evaluation results demonstrate the clinical potential of this probe to selectively target melanoma.
\end{abstract}

Key Words: melanoma; C-11methoxybenzamide; cell binding; biodistribution; microPET imaging

J Nucl Med 2017; 58:827-832

DOI: 10.2967/jnumed.116.184564

$\mathbf{M}$

elanoma accounts for a small percentage of all skin cancer cases, but $75 \%$ of deaths from skin cancer are associated with

Received Sep. 20, 2016; revision accepted Dec. 7, 2016.

For correspondence or reprints contact: Pradeep K. Garg, Center for Molecular Imaging and Therapy, Biomedical Research Foundation, 1505 Kings Highway, Shreveport, LA 71133.

E-mail: pgarg@biomed.org

Published online Dec. 15, 2016.

COPYRIGHT (C 2017 by the Society of Nuclear Medicine and Molecular Imaging. melanoma. A 10-y survival for clinical stage I melanoma patients is $95 \%$ and drops to $10 \%-15 \%$ for stage IV melanoma patients (1). Therefore, early diagnosis and accurate assessment of metastatic lesions are crucial for improved outcome and disease-free survival (2).

Although PET imaging with ${ }^{18} \mathrm{~F}-\mathrm{FDG}$ is routinely used to diagnose a variety of cancers (3), its failure to detect small tumor lesions makes it ineffective for the initial staging of American Joint Commission on Cancer's stage I, II, or III melanoma $(4,5)$. ${ }^{18}$ F-FDG PET failed to detect melanoma in all 14 patients showing a positive sentinel lymph node biopsy for cancer (6). Therefore, the development of a novel PET diagnostic probe with high specificity and selectivity for melanomas has been the goal of many investigators $(7-10)$.

Toward that goal, previously we reported the synthesis of a ${ }^{18}$ F-benzamide $\left({ }^{18} \mathrm{~F}\right.$-DAFBA), a potential PET probe to image melanoma (10). Further evaluations of this probe by other investigators show promising results (11). Nonetheless, its synthesis takes approximately $3 \mathrm{~h}$ and 2 or more purifications $(10,11)$. Recently, several other ${ }^{18} \mathrm{~F}$-benzamides were evaluated to assess their potential to target melanoma (12-15). Although the synthesis time of MEL050 (12) and ${ }^{18} \mathrm{~F}-\mathrm{FPDA}$ (15) was shorter, the in vitro and in vivo properties of these benzamides were even less optimal than that of ${ }^{18} \mathrm{~F}$-DAFBA. Therefore, to develop a probe with facile radiochemical synthesis while bearing biologic properties similar to or better than ${ }^{18} \mathrm{~F}$-DAFBA, we focused our efforts toward developing its ${ }^{11} \mathrm{C}$ analog. Although ${ }^{18} \mathrm{~F}$ compounds offer the convenience of using it at facilities remote from the manufacturing site, ${ }^{11} \mathrm{C}$-labeled PET probes offer an added advantage of using an unaltered chemical moiety. Despite technical challenges posed by the short half-life of radionuclides, ${ }^{11} \mathrm{C}$-choline, ${ }^{11} \mathrm{C}$-methionine, ${ }^{11} \mathrm{C}$-Pittsburgh compound $\mathrm{B},{ }^{11} \mathrm{C}-\mathrm{PK} 11195,{ }^{11} \mathrm{C}$-nicotine, and ${ }^{11} \mathrm{C}-\alpha$-methyltryptamine are extensively used as diagnostic probes in the clinics (16-21). The short half-life of ${ }^{11} \mathrm{C}$ has an added benefit that it delivers lower radiation dose to the subject, thus allowing for same-day follow-up scans or procedures. Herein, we report the synthesis, radiochemistry, and preclinical evaluation of $4-{ }^{11} \mathrm{C}$-methoxy $\mathrm{N}$-(2-diethylaminoethyl) benzamide $\left(4-{ }^{11} \mathrm{C}-\mathrm{MBZA}\right)$ as a PET imaging probe to target melanoma.

\section{MATERIALS AND METHODS}

C-18 plus Sep-Pak cartridges were obtained from Waters Corp. Highperformance liquid chromatography (HPLC) was performed in isocratic mode using a Varian HPLC system equipped with an LC pump, a variable ultraviolet/visible wavelength detector set at $254 \mathrm{~nm}$, and an in-line radioisotope detector (Bioscan). The HPLC column for the purification of $4-{ }^{11} \mathrm{C}-\mathrm{MBZA}$ was a C-18 reversed-phase, $10 \times 250 \mathrm{~mm}$, $5 \mu$ Phenomenex Prodigy column eluted at a flow rate of $3 \mathrm{~mL} / \mathrm{min}$ using 
a solution of methanol:0.1 M ammonium acetate (50:50) containing trimethylamine $(40 \mu \mathrm{L} / 100 \mathrm{~mL})$. The quality of the purified product was checked using a C-18 column $(4.6 \times 250 \mathrm{~mm}, 5 \mu)$, eluted at a flow rate of $1.5 \mathrm{~mL} / \mathrm{min}$ using methanol:0.1 $\mathrm{M}$ ammonium acetate (65:35) containing trimethylamine $(0.04 \%$ solution $)$.

Melanoma cells (B16F1), breast epithelial cells (MCF-10A), and breast cancer cells (MDA-MB-231) were purchased from the American Type Culture Collection. The C57BL/6 mice were purchased from Charles River Laboratories. All animal studies were performed using approved protocols of the Institutional Animal Care and Use Committee and under the guidelines established by the Wake Forest University Health Sciences Institutional Animal Care and Use Committee.

\section{Preparation of $\mathbf{N}$-(2-diethylaminoethyl) \\ 4-Methoxybenzamide (4-MBZA)}

A solution of 4-methoxybenzoyl chloride $(1.0 \mathrm{~g}, 5.8 \mathrm{mmol})$ in $50 \mathrm{~mL}$ of dichloromethane was cooled to $0^{\circ} \mathrm{C}$, and triethylamine $(0.82 \mathrm{~mL}, 5.8$ mmol) and $N, N$-diethylethylenediamine $(0.68 \mathrm{~g}, 5 \mathrm{mmol})$ were added. After being stirred overnight at room temperature, the reaction mixture was poured into ice-cold water $(250 \mathrm{~mL})$, and the contents were extracted with dichloromethane. The organic layer was washed with $1 \mathrm{M}$ sodium bicarbonate solution and dried over magnesium sulfate. After the solvent was removed on a rotary evaporator, the oily residue was purified using a silica-gel column and methanol/dichloromethane (3/97) as the eluent. The 4-MBZA was collected as a yellowish light oil (700 $\mathrm{mg}, 48 \%), \mathrm{C}_{14} \mathrm{H}_{22} \mathrm{~N}_{2} \mathrm{O}_{2},{ }^{1} \mathrm{H}$ NMR $(\mathrm{CDCl} 3, \delta): 1.04(\mathrm{t}, 6 \mathrm{H}, \mathrm{J}=7.2 \mathrm{~Hz}$, $\left.2 \times-\mathrm{CH}_{2}-\mathrm{CH}_{3}\right), 2.57\left(\mathrm{q}, 4 \mathrm{H}, \mathrm{J}=7.2 \mathrm{~Hz}, 2 \times-\mathrm{CH}_{2} \mathrm{CH}_{3}\right), 2.65(\mathrm{t}, 2 \mathrm{H}, \mathrm{J}=$ $\left.5.8 \mathrm{~Hz},-\mathrm{CH}_{2}-\mathrm{N}-\left(\mathrm{CH}_{2}-\mathrm{CH}_{3}\right)_{2}\right), 3.47\left(\mathrm{q}, 2 \mathrm{H}, \mathrm{J}=5.2 \mathrm{~Hz},-\mathrm{CONH}-\mathrm{CH}_{2}-\right)$, 3.85 (s, 3H, -O-CH $), 6.85$ (br S, 1H, -NH), 6.89-6.96 (m, 2H, Ar-H- C3 and $\mathrm{C} 5-)$, 7.71-7.78 (m, 2H, Ar-H- C2 and C6-). Electrospray ionization mass spectrometry $\mathrm{m} / \mathrm{z}[\mathrm{MH}]+$ calculated 251 , found 250.99 .

\section{Preparation of 4-Hydroxy N-(2-Diethylaminoethyl) Benzamide (4-HBZA)}

Thionyl chloride $(30 \mathrm{~mL})$ was added to a mixture of 4-acetoxy benzoic acid $(7.4 \mathrm{~g}, 43 \mathrm{mmol})$ in dimethylformamide $(0.5 \mathrm{~mL})$, and the solution was refluxed for $4 \mathrm{~h}$. Excess thionyl chloride was removed using a rotary evaporator. Residual thionyl chloride was removed by adding diethyl ether to the solution $(3 \times 50 \mathrm{~mL})$ and evaporating it on a rotary evaporator. Finally, the oily residue was dissolved in dichloromethane cooled to $0^{\circ} \mathrm{C}$, and triethylamine $(6 \mathrm{~mL}, 43 \mathrm{mmol})$ and $N$, $\mathrm{N}$-diethylethylenediamine (5 g, $43 \mathrm{mmol})$ were added slowly. After being stirred at room temperature overnight, the reaction mixture was poured into ice-cold water and the contents were extracted using dichloromethane. The organic layer was washed with $1 \mathrm{M}$ sodium bicarbonate solution and dried over magnesium sulfate. The solvent was removed using a rotary evaporator, and $50 \mathrm{~mL}$ of sodium methoxide in methanol $(0.5 \mathrm{M})$ were added. After being stirred for $24 \mathrm{~h}$ at room temperature, the solvent was evaporated and the residue was dissolved in $200 \mathrm{~mL}$ of dichloromethane. The organic layer was successively washed with water $(50 \mathrm{~mL}), 1 \mathrm{M}$ hydrochloric acid $(50 \mathrm{~mL})$, water $(100 \mathrm{~mL})$, and then dried over magnesium sulfate. After the solvent was removed, the crude product was purified using flash chromatography. The column was eluted with methanol/ dichloromethane (5/95), and 4-HBZA was obtained as light yellow oil (4.1 g, 40\%). Thin-layer chromatography (silica gel) developed in dichloromethan:methanol (6:4) showed a single spot $\left(\mathrm{R}_{\mathrm{f}} 0.22\right)$. $\mathrm{C}_{13} \mathrm{H}_{20} \mathrm{~N}_{2} \mathrm{O}_{2} ;{ }^{1} \mathrm{H}$ NMR $\left(\mathrm{CDCl}_{3}, \delta\right): 1.07$ (t, $6 \mathrm{H}, \mathrm{J}=7.2 \mathrm{~Hz}, 2 \times-\mathrm{CH}_{2}-$ $\left.\mathrm{CH}_{3}\right), 2.66\left(\mathrm{q}, 4 \mathrm{H}, \mathrm{J}=7.2 \mathrm{~Hz}, 2 \times-\mathrm{CH}_{2} \mathrm{CH}_{3}\right), 2.72(\mathrm{t}, 2 \mathrm{H}, \mathrm{J}=5.9 \mathrm{~Hz}$, $\left.-\mathrm{CH}_{2}-\mathrm{N}-\left(\mathrm{CH}_{2}-\mathrm{CH}_{3}\right)_{2}\right), 3.55$ (q, $\left.2 \mathrm{H}, \mathrm{J}=5.2 \mathrm{~Hz},-\mathrm{CONH}-\mathrm{CH}_{2}-\right), 6.74-6.80$ (m, 2H, Ar-H- C3 and C5-), 6.87 (br S, 1H, -NH), 7.13 (br S, 1H, -OH), 7.58-7.65 (m, 2H, Ar-H - C2 and C6-). Electrospray ionization mass spectrometry $\mathrm{m} / \mathrm{z}[\mathrm{MH}]^{+}$calculated 237 , found 236.93 .

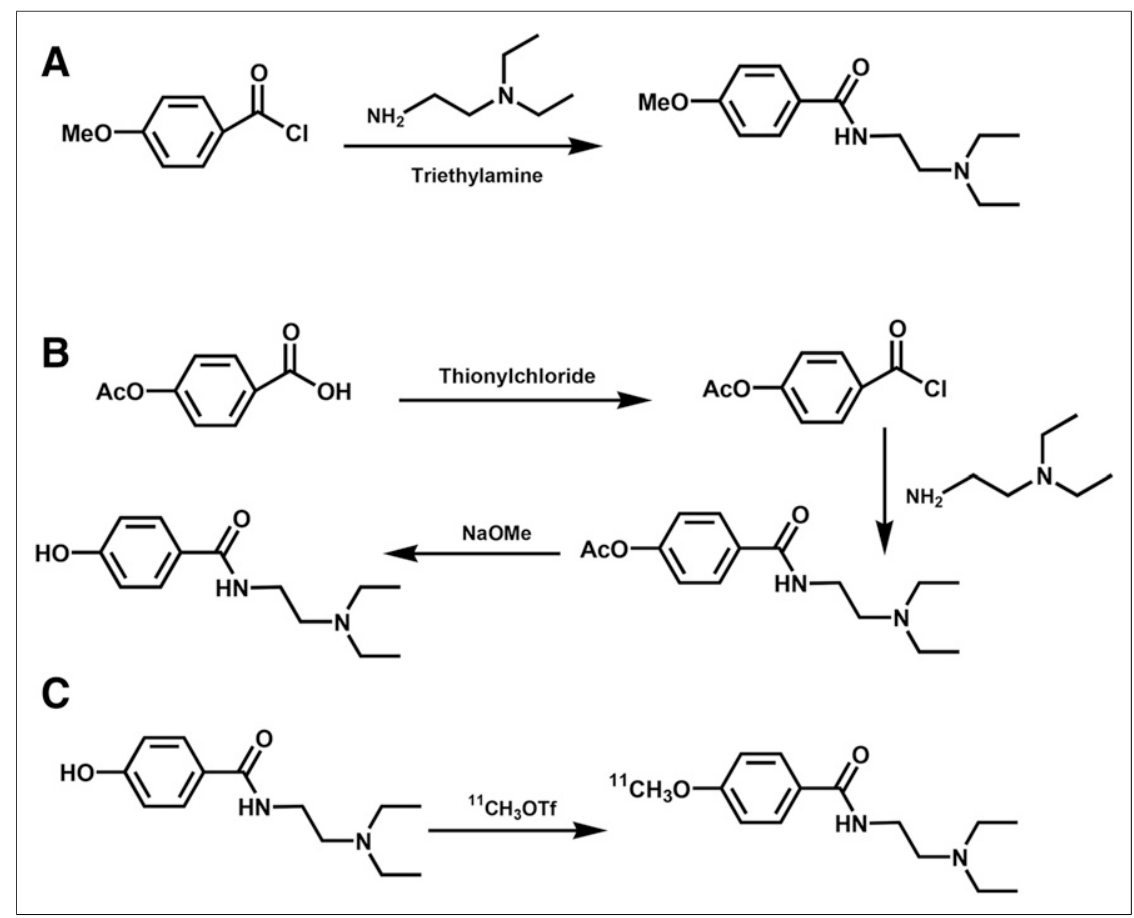

FIGURE 1. Reaction schemes to synthesize precursors and reference standards. (A) One-step synthesis to prepare 4-MBZA is shown. This compound is prepared as reference standard for radiolabeled title compound. (B) Three-step synthesis of precursor 4-HBZA is shown. (C) Radiochemical synthesis of $4-{ }^{11} \mathrm{C}-\mathrm{MBZA}$ was accomplished via radiomethylation of $4-\mathrm{HBZA}$ with ${ }^{11} \mathrm{C}$ methyl-triflate.

\section{Radiochemical Synthesis of 4- ${ }^{11} \mathrm{C}-\mathrm{MBZA}$}

Initially, 33.3-55.5 GBq $(900-1,500 \mathrm{mCi})$ of ${ }^{11} \mathrm{C}-\mathrm{CO}_{2}$ were converted to ${ }^{11} \mathrm{C}$-methyliodide using a FXc Pro synthesis module (GE Healthcare) and subsequently passed through a silver-triflate column (22). The ${ }^{11} \mathrm{C}$-methyltriflate thus obtained was bubbled through a solution of 4-HBZA ( $10 \mu \mathrm{g}$ in $300 \mu \mathrm{L}$ of acetonitrile) containing sodium hydroxide $(0.6 \mathrm{M}$, $20-100 \mu \mathrm{L})$. The reaction was heated at $80^{\circ} \mathrm{C}$ for $2 \mathrm{~min}$. The reaction mixture was loaded on a reversed-phase semiprep HPLC column. The product peak was collected in a flask containing $60 \mathrm{~mL}$ of water, and the contents were passed through a C-18 Sep-Pak to trap the desired product on the Sep-Pak cartridge. The cartridge was washed with $10 \mathrm{~mL}$ of water, and the desired product was eluted from the Sep-Pak using $1 \mathrm{~mL}$ of ethanol followed by $9 \mathrm{~mL}$ of saline and collected in the product vial.

In Vitro Binding Assay. B16F1, MCF-10A, and MDA-MB 231 cells were grown in flasks to $80 \%-90 \%$ confluence, trypsinized, washed in phosphate-buffered saline $(\mathrm{pH} 7.4)$, replated into culture dishes, and allowed to adhere overnight. Initially, 12 -well plates containing approximately $2.5 \times 10^{5}$ cells/well were incubated with $4-{ }^{11} \mathrm{C}-\mathrm{MBZA}$ in quadruplicate sets for $1,15,30,45$, and $60 \mathrm{~min}$ at $37^{\circ} \mathrm{C}$. The medium was removed, and each well was washed with ice-cold medium 
$(2 \times 1 \mathrm{~mL})$. The adherent cells were removed by lysing cells in 500 $\mu \mathrm{L}$ of phosphate-buffered saline containing $10 \%$ Triton X-100. The combined washes and lysate were analyzed for radioactivity content using a $\gamma$-counter.

The next experiment was performed to evaluate the effects of saturating the binding sites with excess nonradioactive 4-MBZA on the binding of $4-{ }^{11} \mathrm{C}-\mathrm{MBZA}$ to the $\mathrm{B} 16 \mathrm{~F} 1$, MCF-10A, and MDA-MB231 cells. Twelve-well plates with approximately $2 \times 10^{5}$ cells/well were treated with $1 \mathrm{~mL}$ of medium (control group) or a $0.16 \mathrm{mM} 4-\mathrm{MBZA}$ solution $\left(40 \mu \mathrm{g}\right.$ of $4-\mathrm{MBZA} /$ well). After $4-{ }^{11} \mathrm{C}-\mathrm{MBZA}$ was added in quadruplicate sets of wells, the plates were incubated at $37^{\circ} \mathrm{C}$ for $30 \mathrm{~min}$. The medium was removed, and each well was washed with ice-cold phosphate-buffered saline $(2 \times 1 \mathrm{~mL})$. The medium and the washes were pooled for each well (phosphate-buffered saline wash). The adherent cells were removed from the wells by lysing with $500 \mu \mathrm{L}$ of $10 \%$ Triton X-100 in phosphate-buffered saline. The radioactivity present in the phosphate-buffered saline wash and corresponding cell lysate was measured using a $\gamma$-counter.

Another experiment assessed the ability of $4-{ }^{11} \mathrm{C}-\mathrm{MBZA}$ to internalize into melanoma cells. The $4-{ }^{11} \mathrm{C}-\mathrm{MBZA}$ was added to wells containing $1.25 \times 10^{5}, 2.5 \times 10^{5}$, and $5.0 \times 10^{5} \mathrm{~B} 16 \mathrm{~F} 1$ cells/well (in quadruplicate), and the plates were incubated at $37^{\circ} \mathrm{C}$ for $30 \mathrm{~min}$. The medium was removed, and each well was washed with ice-cold phosphate-buffered saline $(2 \times 1 \mathrm{~mL})$ and collected in tubes (phosphate-buffered saline wash). Each well was gently treated with $1 \mathrm{~mL}$ of an ice-cold mildly acidic medium (sodium acetate buffer, $\mathrm{pH} 4.5$ ) to remove surface-bound radioactivity, and the rinses were collected in tubes (acid wash). The adherent cells were lysed using $500 \mu \mathrm{L}$ of $10 \%$ Triton X-100 in phosphate-buffered saline. The total radioactivity in the lysate, acidic wash, and phosphate-buffered saline wash was measured.

In Vivo Studies. Six- to 8-wk-old male C57BL mice were inoculated with $0.1 \mathrm{~mL}$ of B16F1 cells $\left(\sim 5 \times 10^{6}\right)$ suspended in a $50 \%$ mixture of Matrigel/phosphate-buffered saline. Mice were injected with approximately $15 \mathrm{MBq}(400 \mu \mathrm{Ci})$ of $4-{ }^{11} \mathrm{C}-\mathrm{MBZA}$ and euthanized at 10,20 , 30,45 , and 60 min after injection. The tissues of interest were removed, washed with phosphate-buffered saline, weighed, and counted for radioactivity using a $\gamma$-counter.

Mice bearing $\mathrm{B} 16 \mathrm{~F} 1$ tumor xenografts were imaged using the $\mathrm{P} 4$ microPET scanner (Concorde Microsystems). 4- ${ }^{11} \mathrm{C}-\mathrm{MBZA}$ was injected via the tail vein, and scans were acquired in list-mode over $45 \mathrm{~min}$. Images were reconstructed using filtered backprojection with attenuation correction, and the data were analyzed using ASIPro software (Siemens). Regions of interest were drawn on select organs using the summed image from the entire 45-min acquisition. The time-activity

TABLE 1

Effect of Temperature and $\mathrm{NaOH}$ Quantity on Radiochemical Yields of $4-{ }^{11} \mathrm{C}-\mathrm{MBZA}$

\begin{tabular}{lccc}
\hline Temperature $\left({ }^{\circ} \mathrm{C}\right)$ & $\begin{array}{c}\mathrm{NaOH} \\
\text { (concentration) }\end{array}$ & $\mathrm{NaOH}(\mu \mathrm{L})$ & Yield $(\%)$ \\
\hline 20 & $0.5 \mathrm{M}$ & 100 & 1 \\
60 & $0.5 \mathrm{M}$ & 100 & 7 \\
60 & $2 \mathrm{M}$ & 100 & 11 \\
60 & $4 \mathrm{M}$ & 20 & 25 \\
40 & $6 \mathrm{M}$ & 20 & 21 \\
60 & $6 \mathrm{M}$ & 20 & 37 \\
80 & $6 \mathrm{M}$ & 20 & 51 \\
100 & $6 \mathrm{M}$ & 20 & 40 \\
\hline
\end{tabular}

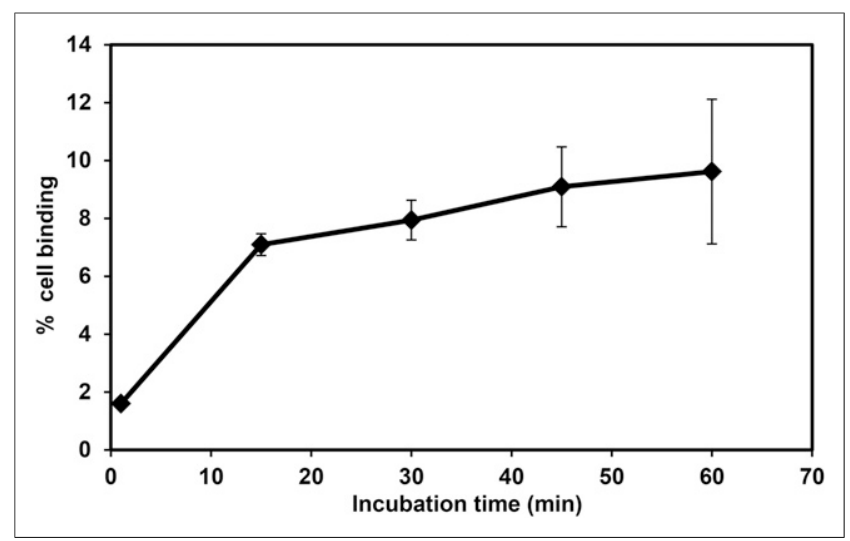

FIGURE 2. 4-11 C-MBZA was incubated with $2.5 \times 10^{5}$ B16F1 cells for $1,15,30,45$, and $60 \mathrm{~min}$ at $37^{\circ} \mathrm{C}$. Results are presented as total cellbound radioactivity (mean $\pm \mathrm{SD}$ ). A 30 -min incubation provided significantly higher binding than $15-\mathrm{min}$ incubation $(P<0.05)$. Binding increased slightly by $60 \mathrm{~min}$, but differences are statistically insignificant $(P>0.1)$.

curves were generated from the list-mode data reconstructed into nine 5-min frames.

\section{RESULTS}

4-MBZA was prepared in $48 \%$ yields, with a greater than $97 \%$ chemical purity, and is shown in Figure 1A. On analytical HPLC, it eluted at approximately 4-5 min and on semipreparatory HPLC column at $13 \pm 2 \mathrm{~min}$. The compound 4-HBZA was synthesized in $40 \%$ yields, with a greater than $99 \%$ chemical purity, and is shown in Figure 1B. The influence of reactants on radiochemical yields is summarized in Table 1 . The radiochemical yield for $4-{ }^{11} \mathrm{C}-\mathrm{MBZA}$ was $46 \% \pm 7 \%$, with a radiochemical purity of greater than $99 \%$ and specific activity of $853 \pm 29.6 \mathrm{GBq} / \mu \mathrm{mol}$

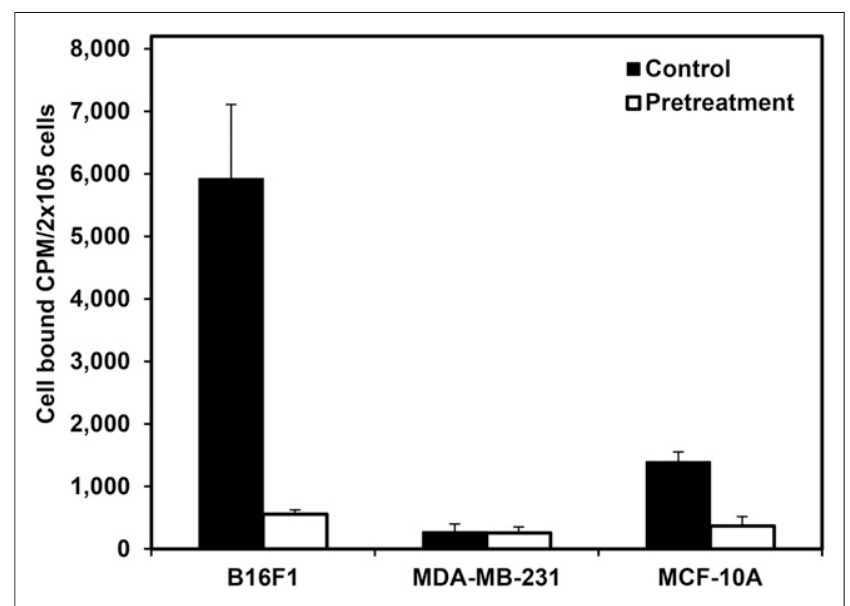

FIGURE 3. Binding of $4-{ }^{11} \mathrm{C}-\mathrm{MBZA}$ to $\mathrm{B} 16 \mathrm{~F} 1$ melanoma cells, MDAMB-321, and MCF-10A $\left(2.5 \times 10^{5}\right.$ cells/well). A preferential binding of 4-11C-MBZA to B16F1 melanoma cells is noted. Pretreatment with excess 4-MBZA to block binding sites resulted in 10-fold reduction in binding to melanoma cells and approximately 4-fold reduction for MCF-10A cells. Binding was low for MDA-MB-231 cells and remained unchanged. 


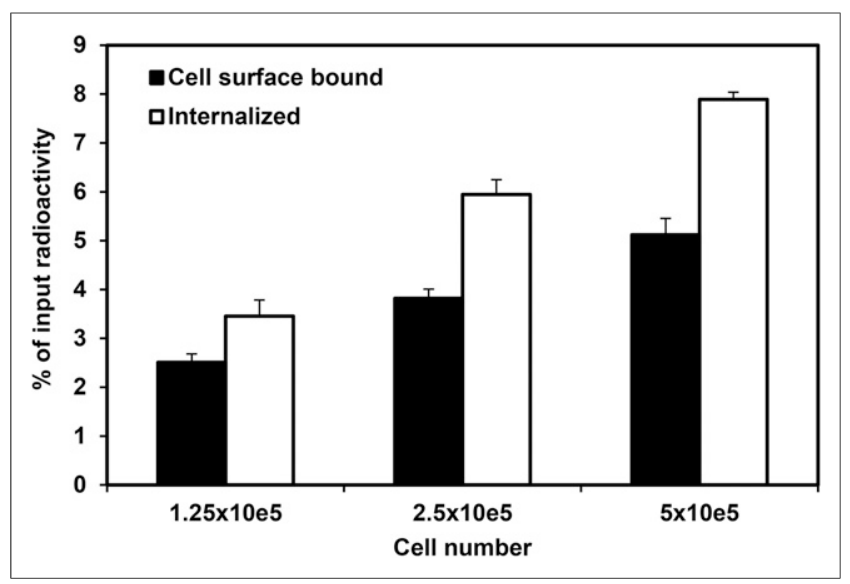

FIGURE 4. Cell-bound and internalized fraction of $4-{ }^{11} \mathrm{C}-\mathrm{MBZA}$ in B16F1 melanoma cells is shown. Overall binding increased proportionally with increased number of cells per well. Nonetheless, internalized fraction remained approximately $55 \%-60 \%$ of total cell associated radioactivity, irrespective of number of cells per well.

$(23 \pm 0.8 \mathrm{Ci} / \mu \mathrm{mol})$ (Fig. 1C). The overall synthesis time was $40 \pm 5$ min.

As shown in Figure 2, the binding of $4-{ }^{11} \mathrm{C}-\mathrm{MBZA}$ to B16F1 cells was rapid and reached $7.94 \% \pm 0.68 \%$ and $9.61 \% \pm 1.38 \%$ at 30 and $60 \mathrm{~min}$, respectively $(P>0.05)$. These values are more than 2 -fold higher than that for the ${ }^{18} \mathrm{~F}$-DAFBA. Figure 3 shows that the binding of ${ }^{4-}{ }^{11} \mathrm{C}-\mathrm{MBZA}$ to $\mathrm{B} 16 \mathrm{~F} 1$ cells is approximately 20-fold and 4-fold higher than its bindings to MDAMB-231 and MCF-10A cells, respectively. The pretreatment with 4-MBZA reduced the binding to B16F1 melanoma cells by approximately 10 -fold and to MCF-10A cells by 4 -fold and did not significantly change for the MDA-MB-231 cells. Inter- nalization experiments using B16F1 cells show that approximately $60 \%$ of total cell-bound activity was internalized as shown in Figure 4.

A rapid accumulation of $4-{ }^{11} \mathrm{C}-\mathrm{MBZA}$ was noted in $\mathrm{B} 16 \mathrm{~F} 1$ melanoma tumors from biodistribution studies, reaching $5.85 \pm 0.79$ and $8.13 \pm 1.46$ percentage injected dose per gram $(\% \mathrm{ID} / \mathrm{g})$ by 10 and $60 \mathrm{~min}$, respectively $(P<0.05)$. The uptake in normal tissues was initially low and decreased further over time. For example, the accumulation in muscles decreased from $2.1 \pm 0.34 \% \mathrm{ID} / \mathrm{g}$ at $10 \mathrm{~min}$ to $0.41 \pm 0.15 \% \mathrm{ID} / \mathrm{g}$ by $60 \mathrm{~min}$, an approximately 5 -fold reduction. Similarly, the radioactivity level in the blood pool was $1.43 \pm 0.29$ and $0.95 \pm 0.25 \% \mathrm{ID} / \mathrm{g}$ at 10 and $60 \mathrm{~min}$, respectively (Table 2). As seen from Figure 5, a high accumulation in tumor and low retention in normal tissues led to a favorable tumor-to-tissue ratio. The tumor-to-lung, -liver, -blood, -muscle, and -brain ratios were $2.57 \pm 0.21,0.94 \pm 0.17,4.17 \pm 0.73,2.78 \pm 0.20$, and $2.39 \pm 0.22$, respectively, at $10 \mathrm{~min}$, and $8.32 \pm 1.62,1.55 \pm 0.26,8.05 \pm 0.83$, $19.04 \pm 6.80$, and $6.86 \pm 1.54$, respectively, at $60 \mathrm{~min}$.

Small-animal PET images shown in Figure 6 exhibit a rapid and high accumulation in the tumor, thus allowing for a clear delineation of tumors within $10 \mathrm{~min}$ after injection. The uptake values calculated from small-animal PET images show that the tumor uptake was $4.2 \% \mathrm{ID} / \mathrm{g}$ by $30 \mathrm{~min}$. As shown in Figure 7, the uptake in normal tissues was low initially and it continued to decrease over time. Nonetheless, the initial uptake in the kidneys (Fig. 7) was high, reaching its peak levels within the first $2.5 \mathrm{~min}$. By $45 \mathrm{~min}$, the kidney levels decreased approximately 5-fold.

\section{DISCUSSION}

Various optimization strategies were tested to improve the radiochemical yields of $4-{ }^{11} \mathrm{C}-\mathrm{MBZA}$. Although the quantity and concentration of sodium hydroxide solution plus the reaction temperature appear to influence the radiochemical yields, the reaction time did not show much influence. The synthesis was automated

TABLE 2

Biodistribution of $4-{ }^{11} \mathrm{C}-\mathrm{MBZA}$ in C57BL Mice Bearing B16F1 Melanoma Tumor Xenografts

\begin{tabular}{lccccc}
\hline & & & & & \\
\cline { 2 - 4 } \multicolumn{1}{c}{ Organ } & $10 \mathrm{Min}^{*}$ & $20 \mathrm{Min}^{*}$ & $30 \mathrm{Min}^{*}$ & $45 \mathrm{Min}^{\dagger}$ & $60 \mathrm{Min}^{\dagger}$ \\
\hline Liver & $6.40 \pm 1.46$ & $5.69 \pm 0.92$ & $5.62 \pm 1.01$ & $5.43 \pm 0.84$ & $4.77 \pm 1.49$ \\
\hline Spleen & $4.52 \pm 0.39$ & $2.59 \pm 0.25$ & $2.22 \pm 0.30$ & $1.59 \pm 0.34$ & $1.37 \pm 0.34$ \\
Lung & $2.30 \pm 0.42$ & $1.23 \pm 0.63$ & $0.89 \pm 0.23$ & $0.79 \pm 0.19$ & $0.81 \pm 0.38$ \\
\hline Heart & $2.36 \pm 0.30$ & $1.25 \pm 0.23$ & $1.12 \pm 0.30$ & $1.02 \pm 0.25$ & $0.83 \pm 0.23$ \\
Kidneys & $7.47 \pm 1.66$ & $4.26 \pm 1.12$ & $3.47 \pm 0.42$ & $3.11 \pm 1.21$ & $3.09 \pm 1.22$ \\
\hline Small intestine & $2.86 \pm 0.43$ & $2.15 \pm 0.29$ & $1.97 \pm 0.28$ & $1.89 \pm 0.59$ & $2.65 \pm 1.14$ \\
Pancreas & $6.48 \pm 0.38$ & $3.48 \pm 0.61$ & $3.52 \pm 0.39$ & $3.49 \pm 1.35$ & $4.62 \pm 1.88$ \\
\hline Bone & $2.68 \pm 0.90$ & $1.33 \pm 0.13$ & $1.04 \pm 0.06$ & $0.83 \pm 0.19$ & $0.80 \pm 0.29$ \\
\hline Brain & $2.46 \pm 0.32$ & $1.66 \pm 0.28$ & $1.28 \pm 0.25$ & $1.25 \pm 0.38$ & $1.08 \pm 0.38$ \\
Adrenals & $1.50 \pm 0.23$ & $0.83 \pm 0.41$ & $0.66 \pm 0.41$ & $0.59 \pm 0.32$ & $0.54 \pm 0.24$ \\
Blood & $1.43 \pm 0.29$ & $0.89 \pm 0.32$ & $1.06 \pm 0.12$ & $1.11 \pm 0.29$ & $0.95 \pm 0.25$ \\
\hline Tumor & $5.85 \pm 0.79$ & $6.13 \pm 0.21$ & $6.20 \pm 0.83$ & $6.86 \pm 1.32$ & $8.13 \pm 1.43$
\end{tabular}

${ }^{*}$ Mean $\pm \mathrm{SD} ; n=4$.

${ }^{\dagger}$ Mean $\pm \mathrm{SD} ; n=7$. 


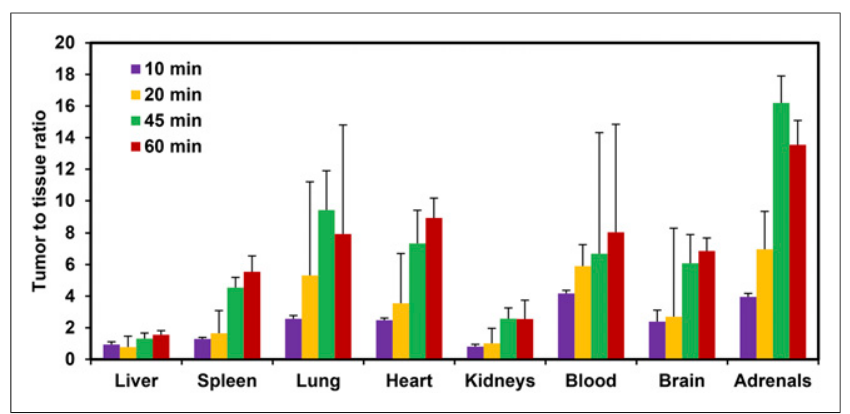

FIGURE 5. Tumor-to-normal tissue ratio at 10, 20, 45, and $60 \mathrm{~min}$ after injection of $4-{ }^{11} \mathrm{C}-\mathrm{MBZA}$ using mice bearing B16F1 melanoma tumor xenografts. For most tissues, these ratios increased significantly with time.

and adapted for routine production on a Tracerlab FXc Pro module (GE Healthcare).

The binding of $4-{ }^{11} \mathrm{C}-\mathrm{MBZA}$ to melanoma cells was rapid and peaked within the first $30 \mathrm{~min}$, a desirable trait for an imaging probe incorporating a short-half-life radionuclide $\left({ }^{11} \mathrm{C}=20 \mathrm{~min}\right)$. 4- ${ }^{11} \mathrm{C}-\mathrm{MBZA}$ showed a greater than 20 -fold-higher binding to B16F1 melanoma cells than to MDA-MB-231 breast cancer cells (Fig. 3). In general, $4-{ }^{11} \mathrm{C}-\mathrm{MBZA}$ binding to melanoma cells was fast and significantly higher than reported for the ${ }^{18} \mathrm{~F}$-DAFBA and ${ }^{18} \mathrm{~F}$-FPBZA. For example, the binding of ${ }^{18} \mathrm{~F}-\mathrm{FPBZA}$ and ${ }^{18}$ F-DAFBA was $4.12 \% \pm 0.2 \%$ (2-h incubation) and $5.62 \% \pm$ $2.67 \%$ (1-h incubation), respectively, using $1 \times 10^{6}$ melanoma cells $(13)$ as compared with $9.61 \% \pm 2.49 \%$ for $4-{ }^{11} \mathrm{C}-\mathrm{MBZA}$ using $2.5 \times 10^{5}$ melanoma cells (Fig. 2). The pretreatment of cells with $160 \mathrm{nmol}$ of $4-\mathrm{MBZA}(40 \mu \mathrm{g})$ resulted in a 10 -fold reduction in binding of ${ }^{4-}{ }^{11} \mathrm{C}-\mathrm{MBZA}$ to melanoma cells. The binding to pretreated cells was low for all the 3 cell lines and perhaps represents the nonspecific binding (Fig. 3).

For the internalization experiments $(23,24)$, the cells were treated with a low $\mathrm{pH}$ buffer to sequester membrane-bound radioactivity from the internalized fraction. Although the overall binding to cells increased with increased density of cells, the internalized fraction remained approximately $60 \%$ of the total cell-associated radioactivity irrespective of the cell density (Fig. 4).

The potential of $4-{ }^{11} \mathrm{C}-\mathrm{MBZA}$ to target melanoma tumors in vivo was assessed using tissue distribution and small-animal PET imag-

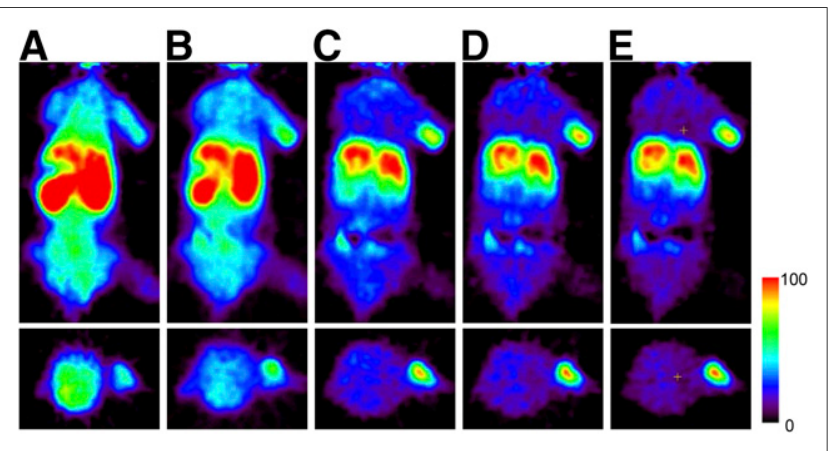

FIGURE 6. Small-animal PET images of mice bearing B16F1 melanoma tumor xenografts after injection of $4-{ }^{11} \mathrm{C}-\mathrm{MBZA}$. Coronal (top) and axial (bottom) views are summed images showing average uptake in scans from 0 to $5 \mathrm{~min}(\mathrm{~A}), 5$ to $15 \mathrm{~min}(\mathrm{~B}), 15$ to $25 \mathrm{~min}(\mathrm{C}), 25$ to $35 \mathrm{~min}(\mathrm{D})$, and 35 to $45 \mathrm{~min}(\mathrm{E})$. Tumor is clearly visible on 5 -min images (A) and continued to increase in intensity with time (B-E).

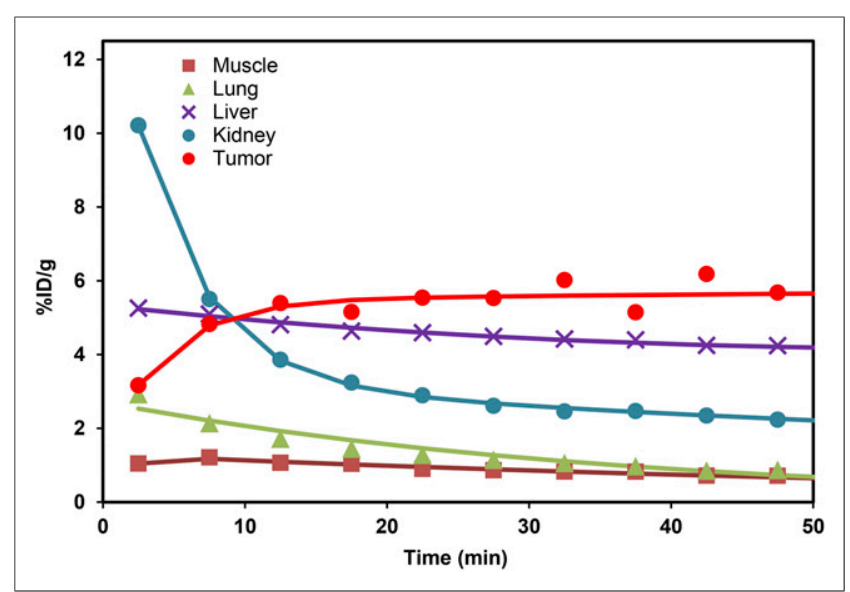

FIGURE 7. Time-activity curves generated from small-animal PET images of mouse bearing B16F1 melanoma tumors and injected with 4- ${ }^{11} \mathrm{C}-\mathrm{MBZA}$. A high uptake was noted in tumor. Accumulation in most normal tissues was low, and it continued to decrease with time.

ing studies with C57BL/6 mice bearing B16F1 melanoma tumor xenografts. The biodistribution studies initially showed a modest uptake of radioactivity in normal tissues, followed by a steady washout with time. In general, a 2- to 5-fold reduction from most normal organs was noted by $60 \mathrm{~min}$ as compared with their peak accumulation levels seen at approximately $10 \mathrm{~min}$ (Table 2). In general, the accumulation of $4-{ }^{11} \mathrm{C}-\mathrm{MBZA}$ in melanoma tumors was significantly high (Table 2) at all time points as compared with ${ }^{18} \mathrm{~F}$-DAFBA. For comparison, the tumor uptake for the 4- ${ }^{11} \mathrm{C}-\mathrm{MBZA}$ and ${ }^{18} \mathrm{~F}-\mathrm{DAFBA}$ was $6.20 \pm 0.83$ and $3.91 \pm$ $2.03 \% \mathrm{ID} / \mathrm{g}$, respectively, at $30 \mathrm{~min}$ and $8.13 \pm 1.43$ and $6.99 \pm$ $2.76 \% \mathrm{ID} / \mathrm{g}$, respectively, at $60 \mathrm{~min}$. The tumor uptake for ${ }^{18} \mathrm{~F}-\mathrm{FPDA}$ was $2.65 \pm 0.48 \% \mathrm{ID} / \mathrm{g}$ at $2 \mathrm{~h}$, a value significantly low (14).

Because the presence of brain metastasis confers a poor prognosis with high mortality (25), the ability of an imaging agent to cross the blood-brain barrier is considered critical to effectively target metastatic lesions in the brain. Nonetheless, it is equally important for the uptake to remain low in the normal brain. The tissue distribution studies show a moderate uptake of $4-{ }^{11} \mathrm{C}-\mathrm{MBZA}$ in the brain at early time points $(2.46 \pm 0.32 \% \mathrm{ID} / \mathrm{g}$ at $10 \mathrm{~min})$, and these levels decreased significantly with time (Table 2), demonstrating the ability of $4-{ }^{11} \mathrm{C}-\mathrm{MBZA}$ to cross the blood-brain barrier and its low nonspecific accumulation. The uptake in other tissues known to anchor melanoma metastases such as the liver, bone, and lungs was low at $10 \mathrm{~min}$, and these levels further decreased with time (Table 2). In general, $4-{ }^{11} \mathrm{C}-\mathrm{MBZA}$ uptake in normal tissues was noticeably lower than that for several of the ${ }^{18} \mathrm{~F}$-benzamides. For example, the uptake in the lungs for the FPBZA (13), MEL050 (12), ${ }^{18} \mathrm{~F}-\mathrm{DAFBA}$, and $4-{ }^{11} \mathrm{C}-\mathrm{MBZA}$ was $3.07 \pm 0.42,2.9 \pm 0.4,2.46 \pm$ 1.27 , and $0.89 \pm 0.23 \% \mathrm{ID} / \mathrm{g}$, respectively, at $30 \mathrm{~min}$. Similarly, the radioactivity accumulation in the spleen and muscles was significantly lower for $4-{ }^{11} \mathrm{C}-\mathrm{MBZA}$ than for the FPBZA, MEL050, and ${ }^{18} \mathrm{~F}-\mathrm{DAFBA}$. In general, $4-{ }^{11} \mathrm{C}-\mathrm{MBZA}$ showed a high propensity toward melanoma and a low retention in normal tissue, thus providing a high tumor-to-tissue ratio (Fig. 5). Therefore, the tumor-tomuscle ratio for $4-{ }^{11} \mathrm{C}-\mathrm{MBZA}$ improved 6-fold, and tumor-to-lung ratio improved more than 3 -fold between 10 and 60 min after injection. Similarly, the tumor-to-liver and -bone ratios improved 2- and 4-fold, respectively, during this time. 
As observed from biodistribution studies, a rapid and high tumor uptake was noted in small-animal PET imaging studies. The tumor was clearly visible by $5 \mathrm{~min}$ after injection, and the uptake intensity continued to increase with time (Fig. 6). With the exception of the liver, for most normal tissues a low accumulation was noted at early time points that was followed by a steady washout of radioactivity, starting at approximately $15 \mathrm{~min}$ after injection (Fig. 7). The uptake and clearance patterns for the kidneys and the urinary bladder indicate renal clearance as the primary route of excretion. In summary, the radiochemical synthesis of $4-{ }^{11} \mathrm{C}-\mathrm{MBZA}$ is facile and provides high radiochemical yields in short synthesis time. The small-animal PET imaging studies demonstrated the capability of $4-{ }^{11} \mathrm{C}-\mathrm{MBZA}$ to clearly delineate melanoma tumors in vivo. Together, these preclinical in vitro and in vivo findings suggest significant potential of $4-{ }^{11} \mathrm{C}-\mathrm{MBZA}$ as a clinically useful probe to target melanoma tumors.

\section{CONCLUSION}

This report covers the development of $4-{ }^{11} \mathrm{C}-\mathrm{MBZA}$ as a promising PET imaging probe to detect melanoma. The radiochemical synthesis is facile, providing the product in high radiochemical yields, with high specific activity and high radiochemical purity. The in vitro binding to melanoma cells is rapid and high. The biodistribution and small-animal PET imaging studies show a rapid and persistent accumulation of $4-{ }^{11} \mathrm{C}-\mathrm{MBZA}$ in melanoma tumors. These preclinical results support the potential of $4-{ }^{11} \mathrm{C}$ MBZA as a probe to selectively target melanoma tumors.

\section{DISCLOSURE}

No potential conflict of interest relevant to this article was reported.

\section{ACKNOWLEDGMENTS}

We thank Kimberly Black, Holly Smith, Leah Rutkowski, and $\mathrm{Li} \mathrm{Wu}$ for their excellent technical help, and Heather Hatcher for assistance with in vivo tumor implantations. The strong support from the Center for Biomolecular Imaging to support this study is greatly appreciated.

\section{REFERENCES}

1. Trinh VA. Current management of metastatic melanoma. Am J Health Syst Pharm. 2008;65:S3-S8.

2. Jost LM. ESMO minimum clinical recommendations for diagnosis, treatment and follow-up of cutaneous malignant melanoma. Ann Oncol. 2003;14:10121013.

3. Wagner JD, Schauwecker D, Davidson D, et al. Inefficacy of F-18 fluorodeoxyD-glucose-positron emission tomography scans for initial evaluation in earlystage cutaneous melanoma. Cancer. 2005;104:570-579.
4. Wagner JD, Schauwecker D, Davidson D, et al. Prospective study of fluorodeoxyglucose-positron emission tomography imaging of lymph node basins in melanoma patients undergoing sentinel node biopsy. J Clin Oncol. 1999;17:1508-1515.

5. Belhocine T, Pierard G, De Labrassinne M, Lahaye T, Rigo P. Staging of regional nodes in AJCC stage I and II melanoma: ${ }^{18}$ FDG PET imaging versus sentinel node detection. Oncologist. 2002;7:271-278.

6. Acland KM, Healy C, Calonje E, et al. Comparison of positron emission tomography scanning and sentinel node biopsy in the detection of micrometastases of primary cutaneous malignant melanoma. J Clin Oncol. 2001;19:2674-2678.

7. Decristoforo C, Hernandez Gonzalez I, Carlsen J, et al. ${ }^{68} \mathrm{Ga}$ - and ${ }^{111} \mathrm{In}$-labelled DOTA-RGD peptides for imaging of $\alpha_{\mathrm{v}} \beta_{3}$ integrin expression. Eur J Nucl Med Mol Imaging. 2008;35:1507-1515.

8. Cheng Z, Zhang L, Graves E, et al. Small-animal PET of melanocortin 1 receptor expression using a ${ }^{18} \mathrm{~F}$-labeled alpha-melanocyte-stimulating hormone analog. $J$ Nucl Med. 2007;48:987-994.

9. Garg S, Kothari K, Black K, et al. $N$-(2-diethylaminoethyl)-4- $\left[{ }^{18} \mathrm{~F}\right]$ fluorobenzamide (DAFBA): a promising PET ligand to image melanoma. $J$ Labelled Comp Radiopharm. 2007;48:18P.

10. Garg S, Kothari K, Thopate SR, Doke AK, Garg PK. Design, synthesis, and preliminary in vitro and in vivo evaluation of $N$-(2-diethylaminoethyl)-4-[ $\left.{ }^{18} \mathrm{~F}\right]$ fluorobenzamide ( $\left[{ }^{18} \mathrm{~F}\right]$-DAFBA): a novel potential PET probe to image melanoma tumors. Bioconjug Chem. 2009;20:583-590.

11. Ren G, Miao Z, Liu H, et al. Melanin-targeted preclinical PET imaging of melanoma metastasis. J Nucl Med. 2009;50:1692-1699.

12. Greguric I, Taylor SR, Denoyer D, et al. Discovery of $\left[{ }^{18} \mathrm{~F}\right] \mathrm{N}-(2$-(diethylamino) ethyl)-6-fluoronicotinamide: a melanoma positron emission tomography imaging radiotracer with high tumor to body contrast ratio and rapid renal clearance. $J$ Med Chem. 2009;52:5299-5302.

13. Wu SY, Huang SP, Lo YC, et al. Synthesis and preclinical characterization of [18F]FPBZA: a novel PET probe for melanoma. Biomed Res Int. 2014;2014:912498.

14. Feng H, Xia X, Li C, et al. Imaging malignant melanoma with ${ }^{18} \mathrm{~F}-5$-FPN. Eur J Nucl Med Mol Imaging. 2016;43:113-122.

15. Liu H, Liu S, Miao Z, et al. A novel aliphatic ${ }^{18} \mathrm{~F}$-labeled probe for PET imaging of melanoma. Mol Pharm. 2013;10:3384-3391.

16. Fallanca F, Picchio M, Spinapolice EG, Ugolini C, Proietti A, Messa C. Imaging of a thymoma incidentally detected by C-11 choline PET/CT. Clin Nucl Med. 2011;36:134-135.

17. Fried D, Garg S, Thomas A, et al. Monitoring treatment response in high risk prostate cancer patients using C-11 choline PET/CT [abstract]. J Nucl Med. 2010; 51(suppl 2):51P.

18. Rottenburger C, Hentschel M, Kelly T, et al. Comparison of C-11 methionine and $\mathrm{C}-11$ choline for PET imaging of brain metastases: a prospective pilot study. Clin Nucl Med. 2011;36:639-642.

19. Zhang S, Smailagic N, Hyde C, et al. ${ }^{11}$ C-PIB-PET for the early diagnosis of Alzheimer's disease dementia and other dementias in people with mild cognitive impairment (MCI). Cochrane Database Syst Rev. 2014;7:CD010386.

20. Kumar A, Asano E, Chugani HT. alpha- $\left[{ }^{11} \mathrm{C}\right]-$ methyl-L-tryptophan PET for tracer localization of epileptogenic brain regions: clinical studies. Biomark Med. 2011;5:577-584.

21. Rose JE, Mukhin AG, Lokitz SJ, et al. Kinetics of brain nicotine accumulation in dependent and nondependent smokers assessed with PET and cigarettes containing ${ }^{11}$ C-nicotine. Proc Natl Acad Sci USA. 2010;107:5190-5195.

22. Jewett DM. A simple synthesis of $\left[{ }^{11} \mathrm{C}\right]$ methyl triflate. Int J Rad Appl Instrum [A]. 1992;43:1383-1385.

23. Bergmann R, Scheunemann M, Heichert C, et al. Biodistribution and catabolism of ${ }^{18} \mathrm{~F}$-labeled neurotensin(8-13) analogs. Nucl Med Biol. 2002;29:61-72.

24. Li X, Liu Q, Wang M, et al. C-11 choline PET/CT imaging for differentiating malignant from benign prostate lesions. Clin Nucl Med. 2008;33:671-676.

25. McWilliams RR, Brown PD, Buckner JC, Link MJ, Markovic SN. Treatment of brain metastases from melanoma. Mayo Clin Proc. 2003;78:1529-1536. 